\title{
Our Political Narratives
}

\author{
Kim Phillips-Fein
}

It has been more than two decades since Alan Brinkley wrote his landmark American Historical Review essay on the "problem of American conservatism." In it he argued that twentiethcentury American historians had overemphasized the "triumph of the progressive-liberal state and of the modern, cosmopolitan sensibility that has accompanied and to a large degree supported it." These themes, sometimes so deeply taken for granted that they were not even fully articulated, had made it almost impossible for historians to take the right seriously. No matter how successful the Republican Party might be in the electoral sphere, he argued, conservatism continued to be portrayed as a minor trend, a historical aberration.

Brinkley's essay laid out an intellectual challenge for a generation, and an entire field of scholarship has emerged to interrogate the roots, development, and persistence of modern American conservatism. But the larger questions that Brinkley posed about reckoning with the strength of conservatism in our larger U.S. history narratives have not been fully answered. As Americans grapple with the Trump presidency, this task seems more pressing than ever. What, after all, is the alternative to the story of liberal progress? What do we mean when we talk about "conservatism" or "the right"? Do we imagine, at its core, grassroots white nationalists and other kinds of reactionary populists? Or do we see it driven by a mobilized elite of business leaders and libertarian activists, hawking a politics of privatization and free markets as well as hostility to taxation, unionism, and the welfare state? Moreover, what do we mean when we talk about liberalism and conservatism - as an oppositional binary-at a time when these labels seem to less and less accurately capture Americans' actual political beliefs, if they ever really did? For example, how do we understand the widespread embrace of freemarket ideas, as well as skepticism toward the welfare state and organized labor, among liberals and Democrats as well as in right-wing circles? What do we do with the fact that many so-called conservatives actually advocate radical change? How should we think about the question of who supports Trump and why? New frameworks and new interpretations are needed to help us better understand the myriad political confusions of our own time.

One way of thinking about the modern American political narrative is to divide it into two key periods: the "age of Roosevelt" and the "age of Reagan." ${ }^{2}$ The "age of Roosevelt," stretching from the 1930s to the 1970s, and first forged by a sense of common national purpose during the Great Depression and World War II, underwrote the basic institutions of the welfare state and the strong labor unions that made possible greater economic equality in the postwar years. But over time, Americans' widely shared commitment to strong public institutions foundered as manufacturing companies fled the United States, business leaders chafed under new competition from Europe and Japan, white working-class voters left the Democratic Party in the wake of the civil rights movement, and grassroots conservative activists sought to capitalize on the political and economic uncertainty. The so-called New Deal order of the mid-century was replaced by a new political faith, which combined a utopian certainty in the ability of the free market to resolve the old economic problems with a fierce cultural conservatism that involved a rejection of any structural efforts to confront the legacy of racism, alongside a

\footnotetext{
${ }^{1}$ Alan Brinkley, "The Problem of American Conservatism," American Historical Review 99, no. 2 (1994): 409-29.

${ }^{2}$ The latter phrase is from Sean Wilentz, The Age of Reagan: A History, 1974-2008 (New York, 2008).

(C) The Author(s) 2018. Published by Cambridge University Press
} 
reassertion of traditional gender and family norms against the pressure of feminism and the gay and lesbian rights movements. ${ }^{3}$

Whereas some historians see the Clinton and Obama presidencies as departures from the ethos of the age of Reagan-others have argued that late-twentieth and early twenty-first century Democratic presidents, too, have been swayed by market ideals to such a degree that older liberal politics have been transformed into neoliberalism. Implicit in both interpretations is an underlying hope that the age of Reagan would end, that the absurdities of the right would in time be revealed, and that eventually, civil rights, feminism, and gay and lesbian rights, and perhaps even the amelioration of the most extreme forms of poverty through new waves of progressive policy-making, would surely triumph. The rise of the modern right might only be a temporary success story-a bump in the road to eventual liberal progress.

Recent years have seen the basic assumptions of this narrative questioned from a range of perspectives. One is cautiously optimistic: Has the liberal state really been as weak in the recent past as the age of Reagan narrative suggests? Haven't many of its core institutions-for example, Social Security—been able to endure, even if in weaker form? ${ }^{4}$ The victories of the women's and gay rights movements: Shouldn't these be seen as genuinely transformative, even if they have been accompanied by intensifying economic inequality? In a way, might not the vigor and vitriol of the contemporary right be interpreted as evidence of how substantially liberal goals have transformed American life? The history of the late twentieth and early twenty-first century is one of struggle and contest, but has the right really triumphed?

A more pessimistic line of interpretation, by contrast, singles out not the conservative post-1970s but the era before it as the "great exception," in the memorable phrase of Jefferson Cowie and Nick Salvatore. ${ }^{5}$ During the New Deal era itself, many regarded the sudden burst of social legislation as a culmination of the fierce class struggles that had shaken the nation since the industrial revolution and the birth of the modern corporation in the late nineteenth century. And for many years after, New Deal-era welfare institutions appeared inviolate. They even helped energize the postwar civil rights movement and other leftist causes by demonstrating the primacy of the federal government vis-à-vis the states. But in light of the electoral successes of the right beginning in the 1970s, and a widening of the gap between rich and poor that resembles the economic inequalities of the first Gilded Age, scholars like Cowie and Salvatore have reassessed the strength and long-term viability of the liberal ascendancy. Perhaps it was never as strong as it once appeared; perhaps it was simply the product of historical accident-the depression and World War II-a momentary hiatus for the old antipathies and inequalities that had proceeded it and would eventually come roaring back again. The New Deal was itself partial and incomplete; the institutions it created were racially exclusionary from the outset. Cowie and Salvatore, in particular, emphasize the impasse that the New Deal and modern liberalism faced in remaking American culture in ways that would lend greater support to a communal or collective ethos, as well as the depth of racism as a guiding force in American life. What other scholars might see as a new turn to neoliberalism is really best understood as a return to very old tendencies.

Yet another approach to modern American political history moves away from the emphasis on political ideology and partisanship, indeed abandons entirely the framework (as Matthew Lassiter has written) that focuses on the conflict between "red" and "blue" America in the

\footnotetext{
${ }^{3}$ See for example the landmark essays in Steve Fraser and Gary Gerstle, The Rise and Fall of the New Deal Order, 1930-1980 (Princeton, NJ, 1990).

${ }^{4}$ For one version of this argument, see Meg Jacobs and Julian Zelizer, Conservatives in Power: The Reagan Years, 1981-1989: A Brief History with Documents (Boston, 2010).

${ }^{5}$ Jefferson Cowie and Nick Salvatore, "The Long Exception: Rethinking the Place of the New Deal in American History," International Labor and Working-Class History no. 74 (2008): 1-32. Also see Jefferson Cowie, The Great Exception: The New Deal and the Limits of American Politics (Princeton, NJ, 2016).
} 
first place. ${ }^{6}$ What matters more than the electoral ebb and flow are deeper structures at the foundations of modern American politics: the rise of the surveillance state through the Federal Bureau of Investigation and the Central Intelligence Agency, the bipartisan support for drug laws that have helped to create mass incarceration, the expansion of the military-industrial complex, and the role of first anticommunism, and then antiterrorism, as rationales for overseas interventions and maintaining the primacy of U.S. power in the world. ${ }^{7}$ The development of these forces over the course of the twentieth century span both liberal and conservative eras, and emphasizing them-looking for the bipartisan commitments that are shared features of the political scene-is what matters most. Historians of race and politics, as well as those of gender and sexuality, sometimes share this conviction in examining the ways in which the underlying structures of racial inequality and racial control, as well as stateencouraged heteronormativity, span the entire century, operating in putatively "liberal" and "conservative" eras alike. ${ }^{8}$

One implication of this view is that there was no "great exception" because there really was no interregnum of greater equality and freedom. The entire history of the twentieth century, according to this view, is best seen in terms of the entrenchment and indeed the expansion of institutions and policies that seem to contradict and make more difficult the entire lived experience of democratic government. It is not that these have been without challenge-social movements have at times sought to take them on. Activists and protesters have been powerful witnesses, and their efforts form a reservoir of hope. But by and large they have failed to change the underlying structures of oppression very much. The more extreme versions of right-wing politics, in this view, are simply a starker expression of tendencies that run throughout American society.

All these interpretations have much to offer. Speaking for myself, I have been drawn especially to approaches that focus on the 1970s and 1980s as a critical turning point: to ask what the alternatives might have been to Reaganism and the rightward shift. What were the paths not taken in the 1970s and 1980s? What other solutions might there have been to the economic problems that materialized at that moment? I have also been interested in trying to look at the evolution of conservative movements-at the elite intellectual and corporate level and also at grass-roots mobilizations well outside of "respectable" circles-to treat them as powerful but not all-powerful, part of an evolving whole, drawing from and amplifying themes that were present in the wider society. The relationship between the growing power and influence of economic elites and the way that this affects the broader political culture, so that even people whose interests might appear to be objectively opposed to those at the upper levels of society come to share certain parts of its politics, continues to seem of tremendous importance, as it has ever since the writings of Richard Hofstadter in the mid-twentieth century. ${ }^{9}$ And I have been drawn to exploring how the liberalism inherited from the New Deal and the postwar years - and the broader intellectual and political world that had made this politics intuitiveshifted after 1980, so that many of the claims of the right, which had previously seemed outlandish, suddenly came to seem like common sense.

The transformations of the 1970s and the 1980s saw one set of expectations and way of understanding the world give way to another. However, rather than separate out the years before and after as two separate moments (the "age of Roosevelt" versus the "age of Reagan"), it seems to me that we should instead look for the connections between the two-the

\footnotetext{
${ }^{6}$ Matthew Lassister, "Political History Beyond the Red-Blue Divide," Journal of American History 98, no. 3 (December 2011): 760-4.

${ }^{7}$ There are many examples of work along these lines, but for example see Beverly Gage's forthcoming work on the Federal Bureau of Investigation and the career of J. Edgar Hoover.

${ }^{8}$ For one example, see Elizabeth Hinton, From the War on Poverty to the War on Crime (Cambridge, MA, 2016); Margot Canaday, The Straight State: Sexuality and Citizenship in Twentieth-Century America (Princeton, NJ, 2009).

${ }^{9}$ Richard Hofstadter, The American Political Tradition (New York, 1948).
} 
ways that the politics of the liberal moment shaped what came afterward. For example, one could explore how the Manichean convictions of Cold War liberalism (which helped fuel an ambivalent commitment to union organizing in the South, and which scuttled any plans for national health care in the late 1940s) led to the creation of a welfare state that was hopelessly hobbled, limited by region, and ultimately incapable of sustaining the genuine security that might have mitigated the various economic pressures of the 1970s. Or one could examine the conspicuous consumption of the years after World War II, fueled by the energy sources that endanger our climate today and driven by fantasies of consumer satisfaction and empowerment that were always divorced from a material sense of what institutions and policies might actually make it attainable. As a result, the expectations of middle-class life that were inherited from the postwar years continue to hover over the present, even though the political economy that once sustained them has been decimated.

The election of Ronald Reagan used to seem to historians to be an end point-the culmination of the conservative movement. But now more than ever it matters to stretch our political histories past the Reagan years. For example, we might look at the relationships between freemarket or "neo-liberal" ideas and the surge of conservative populism, at the ways that the attacks on working-class organizations which followed the election of Reagan helped to create a far more atomized population-one that would be more amenable to different forms of conservative politics. Or we should consider the ways that the decline of industry, the growing importance of the service sector and the expansion of finance, and the increasing economic instability and inequality associated with the past forty years have shaped political ideologies and activism. ${ }^{10}$ Most broadly, scholars should explore the inability of liberalism to deliver fully on its promises in the postwar years and the ways in which this failure helped to set the stage for a politics of frustration, reaction, and division-one that continues today. ${ }^{11}$

For any serious student of American history, there have been few moments when it was easy to write political history that ended on a fundamentally optimistic note-in which the trials and tribulations of the past had been finally transcended, the "arc of the moral universe" being long but bending to justice in the end. Today that history seems more difficult to write than ever. But the alternative should not be ironic skepticism, and still less a flight from politics and history altogether. Political history is at its heart the history of the efforts of people to create their world with some degree of choice and conscious reflection. Even when focused on the actions of those who, because of their access to wealth and power, possess agency that is not available to most of us, most of the time, it illuminates the extent to which our society emerges out of a series of decisions, albeit those made under constraints and often circumstances beyond our control - decisions that could be made differently and that would, if they were, produce a different world. As such, the study of political history, with clarity and without sentimentalism, remains a defense against the pervasive sense of powerlessness that is the deepest affliction of our own day.

Kim Phillips-Fein is associate professor at the Gallatin School for Individual Study and the History Department of the College of Arts and Sciences at New York University. She is the author of Invisible Hands: The Businessmen's Crusade Against the New Deal (W.W. Norton, 2009) and Fear City: New York's Fiscal Crisis and the Rise of Austerity Politics (Metropolitan Books, 2017).

\footnotetext{
${ }^{10}$ For two examples of work in this vein, see Bethany Moreton, To Serve God and Wal-Mart: The Making of Christian Free Enterprise (Cambridge, MA, 2009); Greta R. Krippner, Capitalizing on Crisis: The Political Origins of the Rise of Finance (Cambridge, MA, 2011).

${ }^{11}$ Ira Katznelson is one scholar whose work has explored these themes throughout his career, from When Affirmative Action Was White: An Untold History of Racial Inequality in Twentieth-Century America (New York, 2005) to Fear Itself: The New Deal and the Origins of Our Time (New York, 2014).
} 